\title{
Quorum quenching for effective control of biofouling in membrane bioreactor: A comprehensive review of approaches, applications, and challenges
}

\author{
Börte Köse-Mutlu ${ }^{1,2^{\dagger}}$, Tülay Ergön-Can ${ }^{1}$, Ismail Koyuncu ${ }^{1,2}$, Chung-Hak Lee $^{3^{\dagger}}$ \\ ${ }^{1}$ National Research Center on Membrane Technologies, Istanbul Technical University, 34469, Maslak, Istanbul, Turkey \\ ${ }^{2}$ Department of Environmental Engineering, Istanbul Technical University, 34469, Maslak, Istanbul, Turkey \\ ${ }^{3}$ School of Chemical and Biological Engineering, Seoul National University, Seoul 08826, Republic of Korea
}

\begin{abstract}
In comparison to alternative advanced wastewater treatment technologies, the main problem associated with membrane bioreactor (MBR) technology, which has become prominent in recent years, is biofouling. Within these systems, biofouling is typically the result of a biofilm layer resulting from bacterial gathering. One biological system that can be employed to interrupt the process of bacterial gathering is called 'Quorum Quenching (QQ)'. Existing QQ applications can be classified using three main types: 1) bacterial/whole-cell applications, 2) direct enzyme applications, and 3) natural sourced compounds. The most common and widely recognized applications for membrane fouling control during MBR operation are bacterial and direct enzyme applications. The purpose of this review was to identify and assess biofilm formation mechanism and results, the suggestion of the QQ concept and its potential to control biofilm formation, and the means by which these QQ applications can be applied within the MBR and present QQ MBR studies.
\end{abstract}

Keywords: Biofouling, Membrane bioreactor, Quorum sensing, Quorum quenching, Wastewater treatment

\section{Introduction}

In the contemporary world, scarcity has become a hot issue. In particular, many areas of the globe currently suffer from a lack of access to clean water and the need for potable and usable water has resulted in the development and increased use of water treatment technologies. According to forecasts produced by von Grebmer [1], by 2050, 52\% of the global population, which is estimated as 4.8 billion people, will have a lack of access to clean water, and this water stress will have significant effects like an increase in the operational costs for water, energy, and food supply. The wastewater that is currently discharged into the environment is the byproduct of both domestic and industrial processes. At present, domestic wastewater is accountable for the highest volumetric ratio in terms of total discharge. As such, as the population increases with the development of humanity, so too does the unit water consumption per capita and the unit pollution loads per capita. Furthermore, discharge standards that are designated according to the total daily mass of pollutants required to protect the quality of receiving waterbody necessitates the treatment of wastewater with high removal efficiencies.

Several types of wastewater treatment techniques are currently in use. These can be broadly classified as physical, chemical and biological. Physical treatment is generally employed as the primary treatment mechanism and is used to help and protect the biological treatment units in which the secondary treatment processes take place. Biological wastewater treatment utilizes both conventional approaches, such as activated sludge systems and rotating biological contactors, and innovative applications like activated sludge systems with modifications and membrane bioreactors (MBR).

The membrane bioreactor utilizes a treatment technology that combines the activated sludge and membrane filtration processes. The membrane can be basically defined as a selective wall that can separate into two different phases [2]. While pollutants cannot
This is an Open Access article distributed under the terms of the Creative Commons Attribution Non-Commercial License (http://creativecommons.org/licenses/by-nc/3.0/) which permits unrestricted non-commercial use, distribution, and reproduction in any medium, provided the original work is properly cited.

Copyright (C) 2019 Korean Society of Environmental Engineers
Received October 31, 2018 Accepted January 14, 2019

${ }^{\dagger}$ Corresponding author

Email: kosebo@itu.edu.tr, leech@snu.ac.kr

Tel: +90-212-285-3789, +82-2-880-7075

ORCID: 0000-0001-9747-5499 (B. Köse-Mutlu) 
pass across through the membrane, treated water can be collected from behind it. Biological treatment in the MBR tank can be realized by the activated sludge via organic matter removal during the life cycles of the microorganisms that exist within it. MBRs have many advantages. The lower HRT value results in a smaller tank volume and, thus, entails that the tank can be placed in a smaller area [3, 4]. In addition to this, high Mixed Liquor Suspended Solid (MLSS) values help MBR systems to tolerate shock loadings $[5,6]$. Moreover, there is no need for the use of clarifiers in the treatment plant because solids are separated from the mixed liquor by means of filtration [7, 8].

The biggest advantage of MBRs is that effluent can find several beneficial usage areas, like irrigation. It is perhaps due to these advantages that the use of MBRs has increased in recent years. According to existing studies in this domain, the global use of MBRs has grown at a rate of between 10 and 15\%, and the total value of the global MBR market, which is 1.81 billion USD in 2016, is expected to witness positive growth in the near future and will be 8.27 billion USD in 2025 [9, 10].

The current market research indicates that MBR technology is increasingly being viewed as a modern and reliable technology; however, uncertainty remains as to the relatively high risks and costs associated with the use of MBRs versus conventional technologies [11]. Furthermore, specific concerns have been raised regarding the fouling problem that is associated with the operation of MBRs. One of the fundamental limitations of all membrane processes is that they result in membrane fouling. Rejected pollutants and microorganisms in the mixed liquor tend to attach to the surface of the filtration membrane. Fouling can result in flux reduction under the constant transmembrane pressure (TMP) or TMP increase under the constant flux, and these changes result in an increase in the unit cost of wastewater treatment [2]. Strategies that are specifically designed to prevent fouling as an output of the MBR operation can be broadly grouped into five different approaches: 1) Physically treating the feed, 2) Physically and chemically cleaning the membrane, 3) Reducing the flux, 4) Increasing the aeration rate, and 5) Making chemical or biochemical modifications to the mixed liquor [2]. Since all of these operation strategies increase the unit treatment cost, researchers have invested a significant amount of effort in identifying alternative methods of preventing fouling that minimizes this cost. Studies on the fouling problem have gradually increased in recent years and generally involve the modification of membrane material or module configuration. However, many people view these studies as insufficient because the modifications proposed are costly and have largely failed to stand the test of time during long-term MBR operations. The reason for this insufficiency is that the creation of biofilm, and the gradual increase of this biofilm, is a totally natural process. Membrane biofouling in the MBR is generally associated with extracellular polymeric substances (EPS) and soluble microbial products (SMP) [12-15]. EPS is a structural material of microbial aggregations, such as biofilm, floc and activated sludge liquor and a term used for macromolecules like carbohydrates, proteins, lipids, and other polymeric substances on the surfaces of the cells or in the gap between the cells [16]. EPS, with its unstable and heterogeneous structure, can create a highly hydrated gel, and this gel structure forms a barrier against the permeate flow during the membrane filtration process [17]. Besides, SMP is used for the definition of cellular compounds created during cell decay, synthesis, etc. [18].

The key aspect of biofilm creation that involves a totally natural process is quorum sensing (QS). QS is the communication between species using signalization. QS microorganisms show several types of group behaviors including EPS and SMP secretions and biofilm creation. Microorganisms in communication with each other start to accumulate in the biofilm and create a bio-cake that has less porosity. In order to prevent this situation, signalization mechanisms have to be interrupted, and this interruption mechanism is known as quorum quenching (QQ). Although the application of QQ in MBRs is a relatively new topic in the area of anti-biofouling MBR studies, there are some examples of the use of QQ within MBRs. For the purposes of this review, existing QQ MBR studies were compiled by evaluating their advantages and disadvantages, and informative explanations on the future potential of this new vision were formulated.

\section{Quorum Sensing}

Bacteria communicate to one another by producing signal molecules, called 'Autoinducers (AIs)' to coordinate their group behaviors. Using these QS signal-response systems, bacteria regulate gene expression in response and synchronize particular behaviors such as bioluminescence, antibiotic production, virulence, biofilm formation, the production of SMP and EPS [19, 20]. These quorum systems are potential targets for biofouling control in MBR because bacteria control the expression of biofilm formation via QS networks. The discovery that bacteria are able to communicate with one another changed our general perception of many single, simple organisms inhabiting our world. However, the concept that bacteria produce pheromones and communicate with one another was met with considerable skepticism by many and disinterest by others in the early 1990s [21]. A schematic drawing of microbial group behaviors via QS, illustrated using data from Greenberg [22], is given in Fig. 1.

Although several QS systems are known, N-Acyl-HSL (AHLs) are the most common signaling molecules used by Gram-negative bacteria and peptide-based signaling systems are used by Gram-positive bacteria [23, 24]. Additionally, both Gram-negative and Gram-positive bacteria produce autoinducer-2 (AI-2), which is a member of a family of signaling molecules used in QS that can facilitate interspecies cell-to-cell signaling.

The first observed QS system based on AHL autoinducer and its cognate regulatory circuit was that of the bioluminescent marine bacterium Vibrio fischeri (V. Fischeri), which was examined as a model for QS in most Gram-negative bacteria. At low cell densities in natural seawater, $V$. fischeri is non-luminescent. However, when it is proliferated to high cell densities in the laboratory, a $V$. fischeri culture bioluminesces with a blue-green light [25]. While the squid host uses the bacterial-produced light for counter illumination to mask its shadow as an anti-predation tactic, the bacteria profits from the nutrient-rich squid and grows to a high cell density that is unachievable in seawater. Two regulatory proteins, called LuxI and LuxR, are essential for QS control of bioluminescence 
in $V$. fischeri. LuxI is the AI synthase enzyme in $V$. fischeri, and it catalyzes the formation of the AHL. Then, AHL molecules freely diffuse out of the cell membrane and accumulate. At high AHI concentrations (high cell density), QS signaling molecule produced by LuxI is bound by LuxR and this AHL-LuxR complex activates

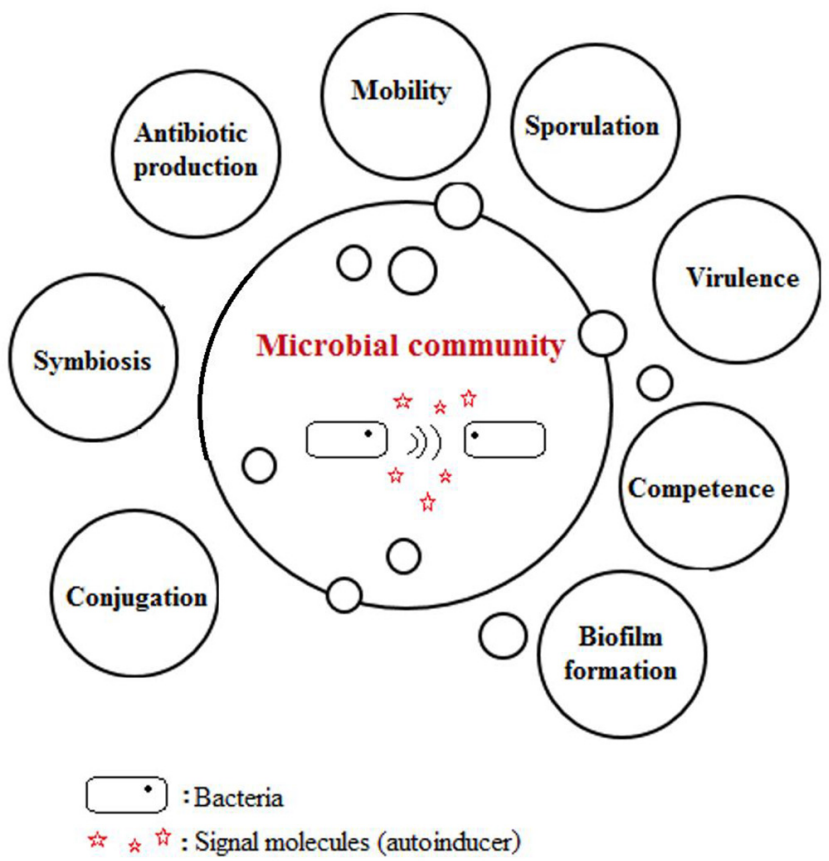

transcription of the LuxICDABE operon. In the absence of an AHL signal, LuxR is inactive. At low cell densities, the AHL signals produced by LuxI diffuse passively out of the cell following a concentration gradient. Thus, the lux operon is not expressed. Different types of AHL-based QS molecules are produced by different bacteria. AHLs are composed of homoserine lactone (HSL) rings that carry acyl chains that differ from $\mathrm{C} 4$ to $\mathrm{C} 18$ in length [26]. A large number of other Gram-negative bacteria possess LuxIR-type proteins and communicate with AHL signals for intraspecies QS [21].

While Gram-negative bacteria use AHLs as auto-inducers, Gram-positive bacteria mostly use secreted peptides as autoinducers for QS. Peptides are encoded in genes and are made as a larger precursor protein (pro-peptides) inside the cell. These are then further processed to small linear or cyclic peptides during secretion. According to Parsek and Greenberg [24]:

"In contrast to AHL-based signaling, peptide signals are not detected inside the cell. In some cases, a membrane-bound sensor protein belonging to the two-component signal transduction family interacts with the peptide. The peptide-bound sensor then activates an associated response regulator, which modulates expression of quorum-sensing-regulated genes. (p. 1)"

The AI-2 quorum-sensing system was first described in Vibrio harveyi and has been implicated in interspecies communication [27]. In all AI-2-producing bacteria, the precursor for the AI-2 signal is 4, 5-dihydroxy-2, 3-pentanedione (DPD), the product of the reaction catalyzed by the LuxS enzyme. Homologs of luxS

Fig. 1. QS mechanism and group behaviors.

Table 1. Quorum Sensing Signals and QS-Controlled Behaviors in Some Bacteria

\begin{tabular}{|c|c|c|c|c|}
\hline QS signals & Bacteria & Signal synthase & Process controlled by QS & Reference \\
\hline 3-oxo-C6-HSL & Vibrio fischeri & LuxI & Bio-luminescence & {$[31,32]$} \\
\hline 3-oxo-C12-HSL & P. aeruginosa & LasI & Virulence production & [33] \\
\hline 3-oxo-C8-HSL & $\begin{array}{l}\text { Agrobacterium } \\
\text { tumefaciens }\end{array}$ & TraI & $\begin{array}{l}\text { Conjugal transfer of the virulence } \\
\text { plasmid }\end{array}$ & {$[34,35]$} \\
\hline C6-HSL & $\begin{array}{l}\text { Chromobacterium } \\
\text { violaceum }\end{array}$ & CvI & $\begin{array}{l}\text { Violacein, antibiotics } \\
\text { and enzyme production }\end{array}$ & [34] \\
\hline C4-HSL, C6-HSL & $\begin{array}{l}\text { Aeromonas hydrophyla, } \\
\text { A. salmonicida }\end{array}$ & AhyI AsaI & $\begin{array}{l}\text { Biofilm formation, } \\
\text { enzyme production }\end{array}$ & {$[36]$} \\
\hline $\begin{array}{l}\text { Diketopiperazines (DKP) } \\
\text { Cyclo(Ala-l-Val) } \\
\text { and cyclo(l-Pro-l-Tyr) }\end{array}$ & $\begin{array}{l}\text { Pseudomonas aeruginosa } \\
\text { E. coli } \\
\text { Proteus mirabilis } \\
\text { Citrobacter freundii } \\
\text { Enterobacter sp. }\end{array}$ & - & $\begin{array}{l}\text { Cross-species } \\
\text { communication }\end{array}$ & [37] \\
\hline Group I thiolactone & Staphylococcus aureus & AIP-I & Virulence & {$[38]$} \\
\hline Group III thioloactone & S. aureus & AIP-III & Virulence & [38] \\
\hline Group IV thioloactone & S. aureus & AIP-IV & Virulence & [38] \\
\hline C4-HSL & Seratia marcescens & SwrI & Swarming & [39] \\
\hline C6-HSL, Oxo-C6-HSL, C8-HSL & $\begin{array}{l}\text { Yersinia enterocolytica, } \\
\text { Y. pseudotuberculosis }\end{array}$ & YenI YpsI & Motility Aggregation & [39] \\
\hline Furanosyl borate diester & Vibrio harveyii & $\mathrm{AI}-2$ & Luminescence & [40] \\
\hline
\end{tabular}


Table 1. Continued

\begin{tabular}{|c|c|c|c|c|}
\hline QS signals & Bacteria & Signal synthase & Process controlled by QS & Reference \\
\hline $\begin{array}{l}(2 \mathrm{R}, 4 \mathrm{~S}) \text {-2-methyl-2,3,3,4-tetrahydroxy } \\
\text { tetrahydrofuran }\end{array}$ & $\begin{array}{l}\text { Salmonella enterica } \\
\text { sv Typhimurum }\end{array}$ & AI-2 & $\begin{array}{l}\text { Virulence gene } \\
\text { expression }\end{array}$ & [41] \\
\hline 3-oxo-C10-HSL & Vibrio anguillarum & VanI & Virulence & [42] \\
\hline Cyclic thiolactone & S. aureus & AIP-II & Virulence & [43] \\
\hline 3OH-C4-HSL & Vibrio harveyi & LuxM & $\begin{array}{l}\text { Bio-luminescence, } \\
\text { biofilm production }\end{array}$ & {$[21]$} \\
\hline C4-HSL & Pseudomonas aeruginosa & RhII & $\begin{array}{l}\text { Biofilm maturation, } \\
\text { adhesion }\end{array}$ & [21] \\
\hline ADPITRQWGD & Bacillus subtilis & ComX & Sporulation & [21] \\
\hline EMRLSKFFRDFILQRKK & S. pneumonie & CSP & Competence & [21] \\
\hline $\begin{array}{l}\text { g-butyrolactones } \\
\text { g-butyrolactone }\end{array}$ & Streptomyces griseus & A-factor & $\begin{array}{l}\text { Induce biosynthesis } \\
\text { of antibiotics }\end{array}$ & {$[21]$} \\
\hline C12-HSL & $\begin{array}{l}\text { Pseudomonas frederiksbergensis } \\
\text { (isolate BT9) }\end{array}$ & AI-2 & $\begin{array}{l}\text { Virulence, } \\
\text { biofilm formation }\end{array}$ & {$[44]$} \\
\hline $\begin{array}{l}\text { C4-HSL, C6-HSL, } \\
\text { 3-oxo-C6-HSL, } \\
\text { 3-oxo-C8-HSL }\end{array}$ & Enterobacter & AI-2 & Virulence & {$[45,46]$} \\
\hline HSL & $\begin{array}{l}\text { Phaeobacter inhibens DSM17395 } \\
\text { Ruegeria sp. KLH11 } \\
\text { Dinoroseobacter shibae }\end{array}$ & AI-2 & Symbiosis & {$[47]$} \\
\hline
\end{tabular}

exist in hundreds of Gram-negative and Gram-positive bacteria, consistent with a role for AI-2 in interspecies communication that allows other luxS-encoding bacteria in a particular environment to contribute to the overall cell-density information [28, 29]. QS signals and QS-controlled behaviors in some bacteria are listed in Table 1, which is adapted and updated from Dobretsov et al. [30].

\subsection{The Role of Quorum Sensing in Biofilm Formation}

Surfaces are important microbial habitats that generally provide enormous access to nutrients, protection from predation and environmental stresses, and a means for cells to remain in a favorable habitat without being washed away. Biofilm formation occurs when bacterial cells grow on surfaces. Bacterial cells that attach to a surface combine through an adhesive matrix secreted by the cells. The matrix is composed of a variety of polysaccharides and proteins. Biofilms utilize nutrients more easily for microbial growth and help prevent the detachment of cells on dynamic surfaces, such as in flowing systems. Biofilms may contain only one or two species or, more commonly, many species of bacteria. As the organisms adhere to a surface, they keep signaling to one another, and ultimately an expression of genes-related biofilm is initiated [48, 49] (Fig. 2). For example, the major intracellular signaling molecules are AHLs in Pseudomonas aeruginosa. As these lactones accumulate according to population density, they are released and subsequently recognized by adjacent cells. The signaling lactones then control the expression of genes that contribute to biofilm formation:

At least four reasons have been proposed for the formation of biofilms. First, biofilms are a means of microbial self-defense

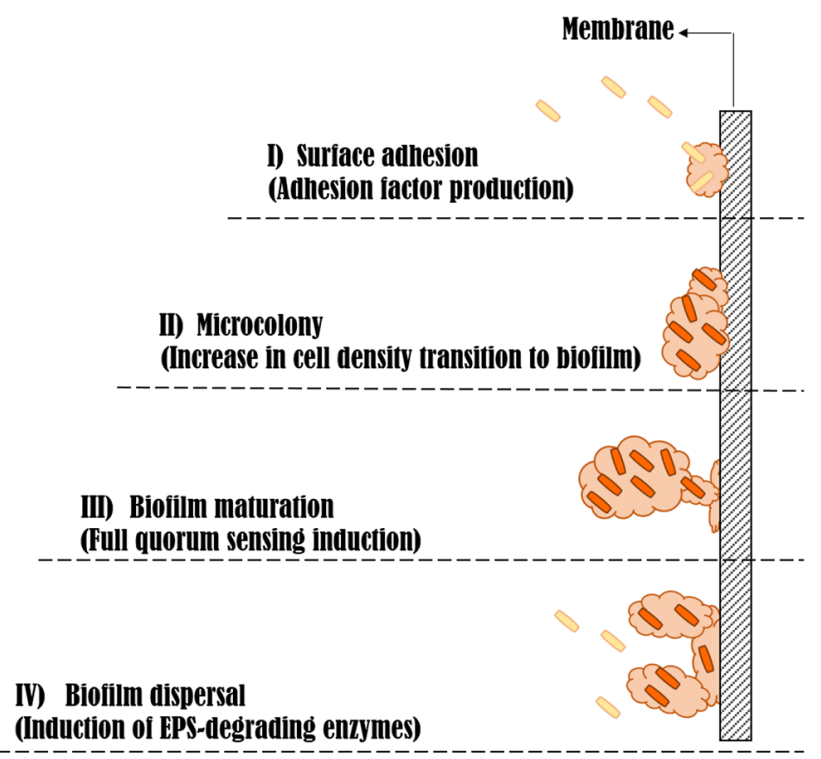

Fig. 2. QS mechanism and group behaviors.

that increase survival. Second, biofilm formation allows cells to remain in a favorable niche. Third, biofilms form because they allow bacterial cells to live in close association with each other. Finally, biofilms seem to be the typical way bacterial cells grow in nature. The biofilm may be the "default" mode of growth for prokaryotes in natural environments, the latter of which differ dramatically in nutrient levels from the rich liquid culture media used in the laboratory [50]. 


\section{Detection of Signal Molecules}

The methods by which qualitative and quantitative determination of AHL signal molecules have been made in the previous QQ MBR studies were also examined within the scope of this review. As previously mentioned, the first QQ MBR study was carried by Yeon et al. [51]. They opted to use Agrobacterium tumafaciens (A.tumefaciens) A136 as a biosensor for AHL detection, based on the works of Fuqua and Winans in 1996 and Kawaguchi et al. in 2008 [52, 53].

A. tumefaciens (Ti-)(pCF218)(pCF372) is a genetically modified microorganism for the detection of exogenous AHL signal molecules. This microorganism has the three following genetic characteristics: 1) Knockout of Ti plasmid (Ti-); 2) pCF 218, which codes for traR; and 3) pCF 372, which contains traI-lacZ fusion, which is under traR regulation. A. tumefaciens A136 cannot produce the AHL autoinducers because the Ti plasmid on which regulatory components of the $A$. tumefaciens QS system are located has been genetically removed. Instead, when exogenous AHL diffuses into A. tumefaciens A136, it makes a complex with TraR protein from the pCF 218. TraR is an AHL-responsive transcription factor that recognizes N-3-(oxooctanoyl)-L-HSL (AHL of $A$. tumefaciens) as well as a wide range of related AHLs. This AHL-TraR complex activates traI-lacZ on pCF 372 and induces the production of beta-galactosidase, which degrades X-gal and develops a blue color. The blue colors spread on an agar plate covered X-gal as shown in Fig. 3(a), and the diameters of these zones are in direct proportion to the AHL concentrations. By using the calibration equation between the diameters and known AHL concentrations, the concentration of AHL in a sample can be calculated.

The concentrations of AHL molecules are also measured via luminescence method using the same reporter strain of

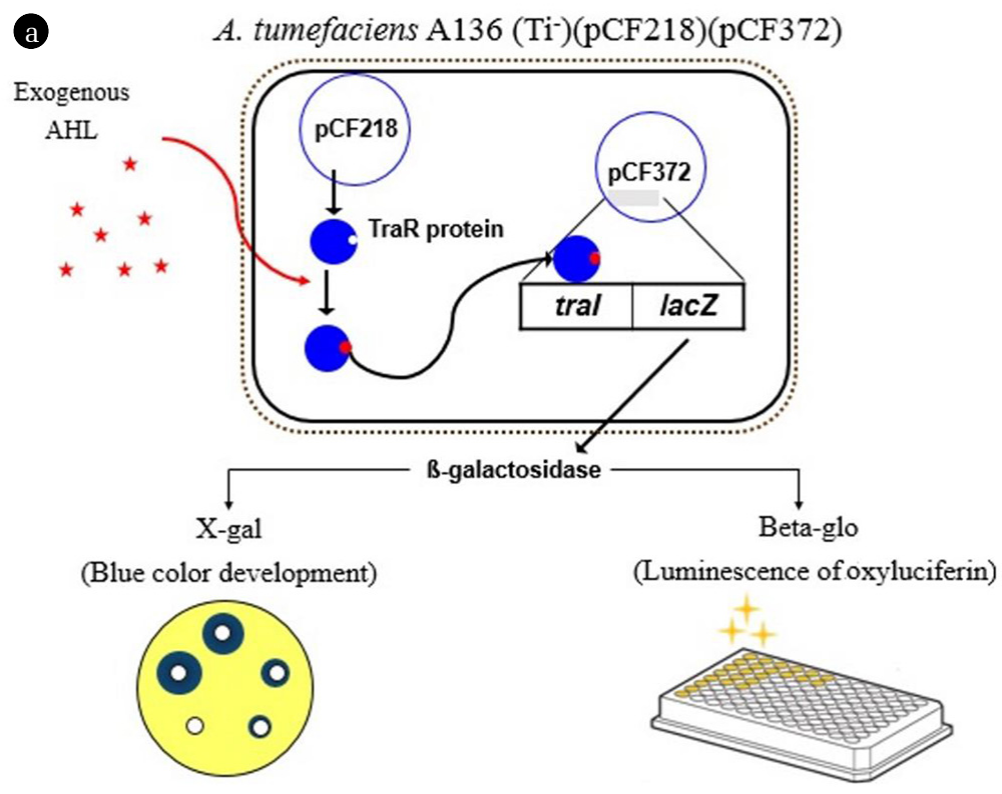<smiles></smiles>

6-O- $\beta$-galactopyranosyl-luciferin

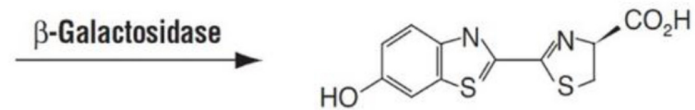<smiles>O=C(O)c1csc(-c2nc3ccc(O)cc3s2)n1</smiles>

D-Luciferin

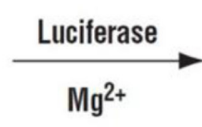

$\mathrm{Mg}^{2+}$

\section{D-Luciferin}

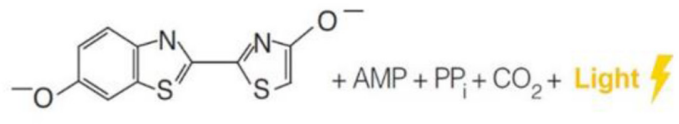

Oxyluciferin

Fig. 3. Bio-assay methods for AHL determination in QQ MBR studies (a) and the reaction with Beta-galactosidase and Beta-glo (b). 
A. tumefaciens A136 [54]. The luminescence method was adopted for the measurement of AHLs in MBR for wastewater treatment by $\mathrm{Oh}$ et al. [55]. The reporter strain (A136) and the AHLs sample are mixed and loaded on the microwell plate. The microwell plate is placed on the incubator to keep the temperature at $30^{\circ} \mathrm{C}$ for $1.5 \mathrm{~h}$, and then the Beta-GloÒ Assay System is added to the solution for the luminescent reaction with b-galactosidase produced by the reporter strain. After $40 \mathrm{~min}$, oxyluciferin is synthesized, resulting in luminescence (Fig. 3(b)). The intensity of luminescence is in direct proportion to the AHL concentration and can be measured by a luminometer. The amounts of AHLs are calculated using relationship equations based on the calibration curve derived from standard samples of AHLs.

The luminometer method is preferred over the agar plate method because the former requires shorter experiment time, leading to the analyses of multiple samples on the same day. The schematic drawing of these two methods for AHL determination is presented in Fig. 3. Although the ultra-sensitive detection of N-Acyl HSL type QS molecules can be realized by bioassay strains like Agrobacterium [56, 57], newly developed techniques have been quite attractive and successful for the signal molecule detection. Ligand-insensitive LuxP mutant fluorescence resonance energy transfer protein sensors could be developed for the detection and quantification of AI-2 QS molecules [58]. Furthermore, Culhane and his colleagues had studied on the development of a new method to create laser-fabricated plasmonic nanostructures for surface-enhanced Raman spectroscopy of bacteria QS molecules. Silver nanostructures were employed in the detection of N-butyryl-L-HSL via Raman signals [59].

\section{Enzymatic Quorum Quenching}

The most common approaches to control bacterial growth in a given environment involve the use of antibiotics; however, it is a well-known fact that bacteria species can develop resistance to these anti-bacterial agents [60, 61]. In addition, the main aim of biofouling prevention during membrane bioreactor operation is not to kill or deactivate all bacteria because a high level of death and deactivation may reduce the efficiency with which pollutants are removed. It is widely recognized that $\mathrm{N}$-acyl Homoserine Lactone (AHL) - mediated QS plays the main role in biofilm creation. As such, some researchers have suggested the use of a new paradigm "QQ" to control the group behaviors of bacteria without affecting their lifecycles [62]. Because the number of Gram-negative bacteria is higher than the number of Gram-positive bacteria in the activated sludge, AHL-mediated QQ has been investigated. There are three main AHL-mediated QQ mechanisms (schematically shown in Fig. 4): 1) Blocking AHL synthesis in the sender cell, 2) Deactivating AHL via enzymatic destruction, and 3) Interfering with the signal receptor in the receiving cell [63].

As mentioned above, the first mechanism involves blocking AHL synthesis. The inhibition of AHL synthesis by blocking LuxI-type synthase proteins is possible and, since AHL is synthesized from S-adenosylmethionine, the analogues of this amino acid can be used to block AHL synthesis [64, 65]. Additional research has found that erythromycin can block AHL synthesis at the ribosomal level through the use of an unknown mechanism [66].

The second mechanism, AHL degradation, is the most well-known mechanism. Enzymatic destruction of AHL molecules can be realized by different types of enzymes, and this prevents AHL accumulating in the environment. Seven different AHL degradation enzymes have been described in the literature. While some of them prefer the decomposition pathway, others use the modification pathway (Fig. 5). The name of QQ enzymes and the final products that result from AHL degradation are presented in Fig. 6.

While lactonases open the homoserine (HSL) ring by disruption of the bond at the left of the double-bonded oxygen [67-69], decarboxylases open this ring by disrupting the bond at the right of the double bonded oxygen [70]. At present, no studies have investigated the mechanism of decarboxylase with a certain bacteria species. In addition, acylases, which has synonyms in the literature like aminase and amidohydrolysis, cleave the acyl side chain from the HSL ring $[65,71]$ and create fatty acid and HSL. Even though there are no examples of studies that have been carried out with a certain bacteria species, deaminase can also cleave the acyl side chain from the HSL ring, but only with a different point. Deaminases create final products as an HSL chain with $\mathrm{OH}^{-}$and a side chain with $\mathrm{NH}_{2}$ [70]. The last example of

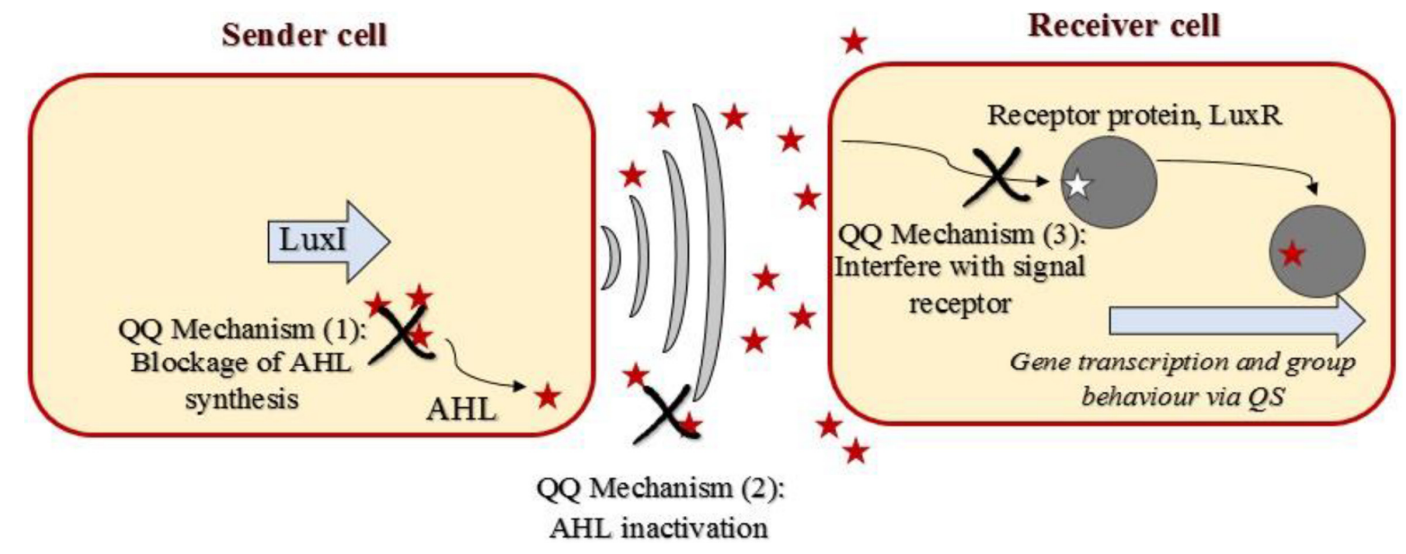

Fig. 4. Main AHL-mediated quorum quenching mechanisms. 


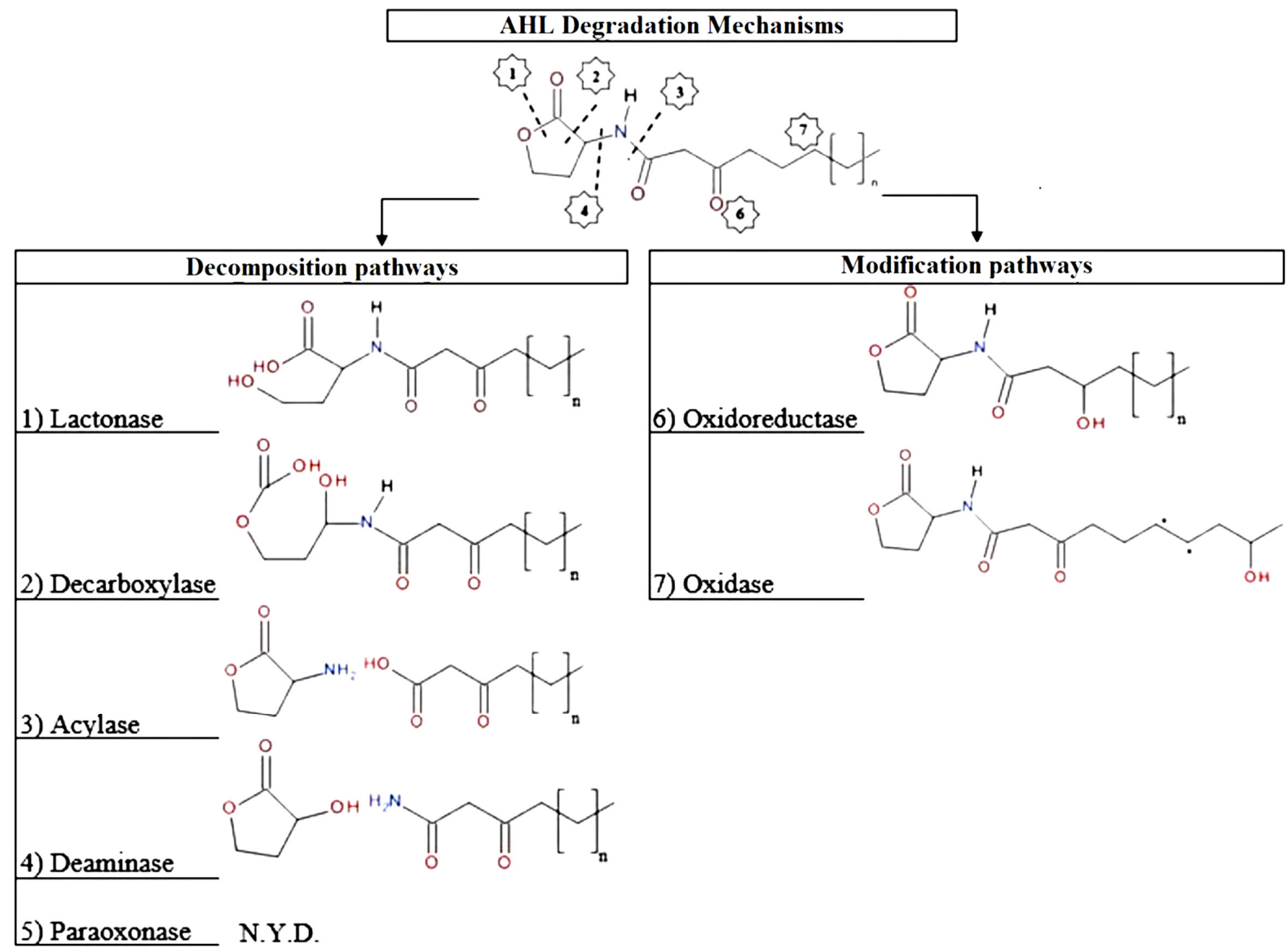

Fig. 5. Enzymatic AHL degradation mechanism and final products (N.Y.D.: Not yet determined).

Table 2. Quorum Quenching Species According to the Enzyme Types

\begin{tabular}{|c|c|c|c|c|}
\hline QQ Enzymes & Source/ Bacterial strains & Gene/ Protein & AHL type & Reference \\
\hline \multirow{13}{*}{ Lactonase } & Mammalian cell & Lactonase & C6-HSL，3-oxo-C12-HSL & {$[75,78]$} \\
\hline & Fungi & n.d. & C6-HSL & [79] \\
\hline & As. Niger IAN 2094 & Glocono lactonase & Lactone ring hydrolysis & [80] \\
\hline & A. Tumafaciens c58 & AttM & 3-oxo-C8-HSL & [69] \\
\hline & Bacillus sp. 240B1 & AiiA & C8-HSL & {$[67,60]$} \\
\hline & B. anthracis & AiiA & C6-HSL, C8-HSL, C10-HSL & [81] \\
\hline & B. cereus & AiiA & C6-HSL, C8-HSL, C10-HSL & [82] \\
\hline & B. mycoides & AiiA & C6-HSL, C8-HSL, C10-HSL & [82] \\
\hline & A. Tumafaciens C58 & AiiB & $\begin{array}{l}\text { 3-oxo-C6-HSL, C6-HSL, C8-HSL, C7-HSL, } \\
\text { 3-oxo-C8-HSL }\end{array}$ & [83] \\
\hline & A. Tumafaciens & AiiB & $\begin{array}{l}\text { C4-HSL, 3-oxo-C6-HSL, C6-HSL, 3-oxo-C8-HSL, } \\
\text { C8-HSL, C10-HSL }\end{array}$ & [84] \\
\hline & Ge. Kaustophilus HTA426 & GKL & $\begin{array}{l}\text { C6-HSL, 3-oxo-C8-HSL, C8-HSL, C10-HSL, } \\
\text { 3-oxo-C12-HSL }\end{array}$ & [85] \\
\hline & M. testaceum StLB037 & AiiM & $\begin{array}{l}\text { 3-oxo-C6-HSL, C6-HSL, 3-oxo-C8-HSL, C8-HSL, } \\
\text { 3-oxo-C10-HSL, C10-HSL }\end{array}$ & [86] \\
\hline & My. Paratuberculosis K-10 & MCP & $\begin{array}{l}\text { C7-HSL, 3-oxo-C8-HSL, C8-HSL, C10-HSL, } \\
\text { C12-HSL }\end{array}$ & [87] \\
\hline
\end{tabular}


Table 2. Continued

\begin{tabular}{|c|c|c|c|c|}
\hline QQ Enzymes & Source/ Bacterial strains & Gene/ Protein & AHL type & Reference \\
\hline \multirow{10}{*}{ Lactonase } & My. Tuberculosis & $\mathrm{PPH}$ & C4-HSL, 3-oxo-C8-HSL, C10-HSL & {$[88]$} \\
\hline & Ochrobactrum sp. T63 & AidH & $\begin{array}{l}\text { C4-HSL, C6-HSL, 3-oxo-C6-HSL, 3-oxo-C8-HSL, } \\
\text { C10-HSL }\end{array}$ & [89] \\
\hline & So. Silverstris StLB046 & AHLs & C10-HSL & [90] \\
\hline & Sul. Solfataricus P2 & SspPox & $\begin{array}{l}\text { 3-oxo-C8-HSL, C8-HSL, 3-oxo-C10-HSL, } \\
\text { 3-oxo-C12-HSL }\end{array}$ & {$[91,92]$} \\
\hline & Rho. Erythropolis W2 & QsdA & $\begin{array}{l}\text { 3-oxo-C6-HSL, C6-HSL, 3-oxo-C8-HSL, C8-HSL, } \\
\text { 3-oxo-C10-HSL, C10-HSL, 3-oxo-C12-HSL, } \\
\text { C12-HSL, 3-oxo-C14-HSL, C14-HSL }\end{array}$ & [93] \\
\hline & Acidobacteria sp. & QIcA & $\begin{array}{l}\text { 3-oxo-C6-HSL, C6-HSL, C7-HSL, 3-oxo-C8-HSL, } \\
\text { C8-HSL, 3-oxo-C10-HSL, C10-HSL }\end{array}$ & {$[94]$} \\
\hline & Arthrobacter sp. IBN110 & AhlD & $\begin{array}{l}\text { C4-HSL, 3-oxo-C6-HSL, C6-HSL, 3-oxo-C8-HSL, } \\
\text { C8-HSL, 3-oxo-C10-HSL, C10-HSL }\end{array}$ & {$[95]$} \\
\hline & Agrobacterium radiobacter $\mathrm{K} 84$ & AiiS & Broad spectrum & [62] \\
\hline & Klebsiella pneumonia KCTC2241 & AhlK & C6-HSL, 3-oxo-C6-HSL & [95] \\
\hline & Rhodococcus sp. BH4 & n.d. & Broad spectrum & {$[93,96]$} \\
\hline Paraoxonase & Mammalian cells & Pon $1,2,3$ & Long chain AHL & {$[78]$} \\
\hline \multirow{15}{*}{ Acylase } & Porcine & Acylase I & $\begin{array}{l}\text { C4-HSL, C6-HSL, 3-oxo-C8-HSL, C8-HSL, } \\
\text { 3-oxo-C10-HSL, 3-oxo-C12-HSL }\end{array}$ & {$[97-102]$} \\
\hline & Ralstonia sp. XJ12B & AiiD & 3-oxo-C8-HSL, 3-oxo-C10-HSL, 3-oxo-C12-HSL & [103] \\
\hline & Anabena sp. PCC7120 & AiiC & C4-HSL, C14-HSL & [104] \\
\hline & Pseudomonas sp. PAI-A & PvdQ & $\begin{array}{l}\text { 3-oxo-C10-HSL, C10-HSL, 3-oxo-C12-HSL, } \\
\text { C12-HSL, C14-HSL, C16-HSL }\end{array}$ & {$[105,106]$} \\
\hline & P. synringae B728a & HacA & C8-HSL, C10-HSL, C12-HSL & [107] \\
\hline & P. synringae B728a & $\mathrm{HacB}$ & C6-HSL, C8-HSL, C10-HSL, C12-HSL & [107] \\
\hline & R. solanacearum GMI1000 & Aac & C7-HSL, C8-HSL, 3-oxo-C8-HSL, C10-HSL & {$[108]$} \\
\hline & Shewanella sp. MIB015 & Aac & C8-HSL, C10-HSL, C12-HSL & [109] \\
\hline & Streptomyces sp. M664 & AhlM & C8-HSL, C10-HSL, 3-oxo-C12-HSL & [110] \\
\hline & P. aeruginosa & QuiP & C6-HSL, C8-HSL, C10-HSL, C12-HSL & [111] \\
\hline & Pseuodomonas sp. 1A1 & n.d. & $\begin{array}{l}\text { C6-HSL, C8-HSL, 3-oxo-C8-HSL, C10-HSL, } \\
\text { 3-oxo-C10-HSL, C12-HSL, 3-oxo-C12-HSL }\end{array}$ & {$[112]$} \\
\hline & V. pradoxus & n.d. & n.d. & {$[69,83]$} \\
\hline & R. eutropha & AiiD & n.d. & [103] \\
\hline & Comamonas & n.d. & n.d. & [113] \\
\hline & Rhodococcus & n.d. & Broad spectrum & {$[114]$} \\
\hline \multirow{4}{*}{ Oxidoreductase } & B. megaterium CYP102A1 & P450BM3 & $\begin{array}{l}\text { Oxidizes; C12-HSL, 3-oxo-C12-HSL, C14-HSL, } \\
\text { 3-oxo-C14-HSL, C16-HSL, C18-HSL, C20-HSL }\end{array}$ & {$[76]$} \\
\hline & Burkholderia sp. GG4 & n.d. & Reduces; 3-oxo-AHL & [114] \\
\hline & Rho. Erythropolis W2 & n.d. & Converts; C8-HSL to C14-HSL & [77] \\
\hline & Rhodococcus & n.d. & Long 3-oxo-AHL & [114] \\
\hline Oxidase & Bacillus megaterium CYP102A1 & P450BM-3 & Long chain AHL & [115] \\
\hline
\end{tabular}

the QQ enzymes that carry degradation pathway is paraoxonase. Paraoxonase is an enzyme that is sourced from mammalian cells, and information about its mechanism has not yet been exactly determined; however, research has proven that it can both disrupt the chain and cleave the side chain of AHL [72-75]. On the other hand, two enzymes can carry the modification pathway: oxidoreductase and oxidase. While oxidoreductase can convert the oxygen that is double bonded to the side chain of $\mathrm{AHL}$ to $\mathrm{OH}^{-}[76,77]$, oxidase modifies the last bond of the side chain [77]. Species that use these QQ enzymes are listed in Table 2. 
The last AHL-mediated QQ mechanism involves interfering with the signal receptor [116, 117]. AHL analogues that compete with receptors have been tested in order to prevent microorganism from receiving QS signals. The analogues can be produced by using side chains of AHL. These compounds interact with LuxR, the receptor protein responsible for AHL, and result in the elimination of AHL [118].

\section{Biofouling Prevention via Quorum Quenching in MBR}

As mentioned, biofilms are unwanted in the MBR process for wastewater treatment because they significantly decrease the permeate flux during membrane filtration and removal of biofilms by chemical treatments may not be sufficient via the tolerance of microorganisms. Since the relationship between QS signal and membrane biofouling was proved, different QQ applications including enzymatic QQ, bacterial QQ, and fungal QQ have been studied in MBR processes for biofouling control. Within the scope of this review, examples of QQ MBR applications that have been developed for the purposes of preventing the biofouling of the filtration membranes located in these MBRs were examined and compiled. A list of the studies examined is presented in Table 3. These studies were listed according to application methods, such as QQ media type. Grouping the research in this way also resulted in them being generally listed chronologically because application methods have changed over time, continuously improving existing methods. In Table 3, QQ applications in MBR were compared to each other in terms of QQ enzyme, QQ microorganism, QQ media, and advantages and disadvantages of QQ method.

Yeon and his colleagues published the first QQ MBR study in 2009. They directly added an enzyme (Acylase) in the MBR to inhibit QS by decomposing signal molecules (AHLs) [51]. They confirmed that the addition of acylase retarded the TMP rise compared with that of the control reactor by regulating EPS concentration. In this study, a QQ mechanism efficiency of $57 \%$ was achieved, and a huge contribution to the literature was realized. However, they observed free enzyme (Acylase) had been rapidly inactivated [102]. Then, they prepared magnetic enzyme carriers (MECs) on which free acylase enzymes were immobilized. By using MECs, not only higher QQ activities were prolonged, but also the immobilization media were easily separated from activated sludge to be reused [102]. Kim et al. [119] immobilized a QQ enzyme (Acylase) onto a nanofiltration membrane and visualized the spatial distribution of cells and polysaccharides on the surface of control and immobilized membranes. They concluded that QQ inhibits polysaccharides and thus mitigates biofilm formation on the acylase immobilized membrane. At the end of these studies that could result in a significant delay of the TMP increase reflecting slower biofilm formation on the membrane surface, it was also surprisingly observed that the inhibition of biofouling by enzymatic QQ was reversible and the following filtration performance of the membrane returned to the original state if $\mathrm{QQ}$ enzyme application interrupted. In the light of these results, it can be mentioned that continuous QQ enzyme addition is indispensable for a con- tinuous biofouling control.

QQ enzymes are commercially available; however, the cost of the enzyme is too high to be applied to MBR for wastewater treatment. Following enzymatic QQ, a lot of bacterial QQ studies have been conducted to seek an economically feasible way [112, 120]. It is obvious that the activity of whole cell catalysts cannot as high as that of isolated enzymes; however, there are three reasons for the preference of bacterial QQ. These reasons can be listed as follows: i) more readily and less expensively preparation, ii) more stability for long-term application as the QQ enzymes inside cells are protected from the external environment (activated sludge), and lastly iii) easier handling. Within this regard, researchers have developed various immobilization media that can interfere with QS continuously. These immobilization media provided protection of immobilized QQ bacteria against other microorganisms in activated sludge and a microporous structure for efficient mass transfer of dissolved oxygen and nutrients. Oh et al. isolated and identified QQ bacteria Rhodococcus sp. BH4 in a real MBR plant and prepared a polymeric microbial vessel containing these QQ bacteria [120]. The polymeric microbial vessel was stimulated as a small tube containing 10-12 hollow fiber membranes. In this study, biofouling was prevented with a success rate of $50 \%$. The polymeric microbial vessel showed reproducible QQ efficiency, delaying TMP rise-up substantially. The location of the vessel in MBR had a direct effect on the QQ efficiency because the vessel is fixed and thus decomposition of signal molecules are very diffusion limited. The QQ vessel was more efficient when it was placed in a membrane tank instead of bio-reactor in MBR [121]. F/M ratio for QQ bacteria in the vessel could be relatively low due to mass transfer limitation. Cheong et al. [122] substituted a ceramic vessel for a polymeric one. The ceramic microbial vessel contained a few lumens through which inner mode feeding was possible. They increased the F/M ratio for QQ bacteria in the ceramic vessel with an inner mode feeding, resulting in a higher QQ efficiency. In addition, the rotation microbial carrier frame (RMCF) was composed of a polycarbonate frame and four cubbyholes that were covered with a microfiltration flat sheet membrane and the usage of RMCF resulted in a higher anti-biofouling effect during MBR operation when compared to the anti-biofouling effect obtained with the usage of normal QQ-vessels [123].

Since vessels have no mobility, moving beads are generally preferred as QQ media in MBR. The advantage of moving QQ beads is the extra physical washing of biocakes deposited on membrane due to their continuous collision to each other. While Jiang et al. immobilized acylase enzymes into globular beads [19], Kim et al. entrapped Rhodococcus sp. BH4 into beads [101] using a natural polymer (sodium alginate). With the combination of biological QQ effect and physical washing effect, 10 times longer time passed to reach the same TMP compared to an MBR without QQ beads (a very high QQ efficiency of 87\%). Jiang et al. achieved efficient biofouling prevention and energy saving, whereas the high cost of enzyme still remained an issue with this application [19]. However, moving microbial beads offered high efficiency and long-term life span.

The only disadvantage of alginate beads is that they are subject to biodegradation in the bioreactor during the MBR operation, leading to short life span. To reinforce alginate beads, Lee et al. 
Table 3. QQ MBR Applications

\begin{tabular}{|c|c|c|c|c|c|}
\hline Immobilization medium & QQ specie & QQ enzyme & Advantages & Disadvantages & Reference \\
\hline - & - & Acylase & No need to encapsulate & Cost and instability of the enzyme & [51] \\
\hline Magnetic enzyme carrier & - & Acylase & Easy recovery & Cost and instability of the enzyme & [102] \\
\hline $\begin{array}{l}\text { Enzyme immobilized } \\
\text { membrane }\end{array}$ & - & Acylase & No need to separate from activated sludge & Cost and instability of the enzyme & [119] \\
\hline $\begin{array}{l}\text { Polymeric microbial } \\
\text { vessel }\end{array}$ & $\begin{array}{l}\text { Rhodococcus } \\
\text { sp. BH4 }\end{array}$ & Lactonase & No need to separate from activated sludge & $\begin{array}{l}\text { Localization of QQ bacteria inside the vessel, } \\
\text { Low mass transfer through the vessel }\end{array}$ & {$[120,121]$} \\
\hline $\begin{array}{l}\text { Polymeric microbial } \\
\text { vessel }\end{array}$ & $\begin{array}{l}\text { Pseudomonas } \\
\text { sp. } 1 \mathrm{~A} 1\end{array}$ & Acylase & No need to separate from activated sludge & $\begin{array}{l}\text { Contamination of exo-enzyme, } \\
\text { Low mass transfer through the vessel, } \\
\text { Localization of QQ bacteria inside the vessel }\end{array}$ & [112] \\
\hline Ceramic microbial vessel & $\begin{array}{l}\text { Pseudomonas } \\
\text { sp. } 1 \mathrm{~A} 1\end{array}$ & Acylase & $\begin{array}{l}\text { High F/M ratio for QQ-bacteria, } \\
\text { No need to separate from activated sludge }\end{array}$ & $\begin{array}{l}\text { Contamination of exo-enzyme, } \\
\text { Low mass transfer through the vessel, } \\
\text { Localization of QQ bacteria inside the vessel }\end{array}$ & {$[122]$} \\
\hline $\begin{array}{l}\text { Rotating microbial carrier } \\
\text { frame }\end{array}$ & $\begin{array}{l}\text { Rhodococcus } \\
\text { sp. BH4 }\end{array}$ & Lactonase & $\begin{array}{l}\text { Even distribution of QQ-bacteria inside } \\
\text { frame via rotation, } \\
\text { Convenience for the larger pilot- and } \\
\text { real-scale MBR plants }\end{array}$ & $\begin{array}{l}\text { Medium F:M ratio, } \\
\text { Inconvenience for small lab-scale MBRs }\end{array}$ & {$[123]$} \\
\hline Sodium alginate beads & - & Acylase & $\begin{array}{l}\text { Extra physical washing effect, } \\
\text { Even distribution of enzyme }\end{array}$ & Cost and bio-instability of the bead, & [19] \\
\hline Sodium alginate beads & $\begin{array}{l}\text { Rhodococcus } \\
\text { sp. BH4 }\end{array}$ & Lactonase & $\begin{array}{l}\text { Extra physical washing effect } \\
\text { Even distribution of QQ-bacteria }\end{array}$ & Bio-instability of the bead, & {$[101]$} \\
\hline $\begin{array}{l}\text { Magnetically-separable } \\
\text { mesoporous silica }\end{array}$ & - & Acylase & $\begin{array}{l}\text { Highly stable and separable material, } \\
\text { Extra physical washing effect }\end{array}$ & Cost and instability of the enzyme & [124] \\
\hline $\begin{array}{l}\text { Sodium alginate bead } \\
\text { covered with the } \\
\text { polymeric membrane } \\
\text { layer }\end{array}$ & $\begin{array}{l}\text { Rhodococcus } \\
\text { sp. BH4 }\end{array}$ & Lactonase & $\begin{array}{l}\text { Extra physical washing effect, } \\
\text { The high mechanical strength of bead, } \\
\text { Even distribution of QQ-bacteria }\end{array}$ & Low mass transfer through the bead & {$[125]$} \\
\hline $\begin{array}{l}\text { (Sodium alginate }+ \text { PVA }) \\
\text { beads }\end{array}$ & $\begin{array}{l}\text { Rhodococcus } \\
\text { sp. BH4 }\end{array}$ & Lactonase & $\begin{array}{l}\text { Extra physical washing effect, } \\
\text { Resistant to biodegradation of beads, } \\
\text { Even distribution of QQ-bacteria }\end{array}$ & Cost of bead & [126] \\
\hline Polymer beads & Candida albicans & AI-2 enzyme & Fungal-to-bacterial $\mathrm{QQ}$ & $\begin{array}{l}\text { The need of economic feasibility for the } \\
\text { pilot- and real-scale plants }\end{array}$ & {$[126]$} \\
\hline $\begin{array}{l}\text { (Sodium alginate + PVA) } \\
\text { cylinder }\end{array}$ & $\begin{array}{l}\text { Rhodococcus } \\
\text { sp. BH4 }\end{array}$ & Lactonase & $\begin{array}{l}\text { Higher mass transfer, } \\
\text { Extra physical washing effect }\end{array}$ & Cost of bead & [127] \\
\hline Hollow-cylinder & $\begin{array}{l}\text { Rhodococcus } \\
\text { sp. BH4 }\end{array}$ & Lactonase & $\begin{array}{l}\text { Higher surface area and enhanced } \\
\text { physical effect }\end{array}$ & $\begin{array}{l}\text { The need of economic feasibility for the } \\
\text { pilot- and real-scale plants }\end{array}$ & [128] \\
\hline Sheets & $\begin{array}{l}\text { Rhodococcus } \\
\text { sp. BH4 }\end{array}$ & Lactonase & Higher surface area & Low durability for long operation & [129] \\
\hline $\begin{array}{l}\text { Carboxylated polyaniline } \\
\text { nanofibers }\end{array}$ & - & Acylase & $\begin{array}{l}\text { No need to separate from activated } \\
\text { sludge, improved stability }\end{array}$ & Cost of enzyme & {$[130]$} \\
\hline
\end{tabular}

[124] immobilized acylase into magnetically-separable mesoporous silica, Kim et al. [125] tried to coat the alginate beads with a synthetic polymer (polysulfone), which prevented QQ bacteria from leaking outside the macrocapsules. Another approach to overcome the disadvantage of alginate beads was to mix a natural polymer, sodium alginate with a synthetic polymer, polyvinylalcohol [126, 127]. Furthermore, there are various studies that are innovative and mention about new QQ MBR applications. First one of these innovative applications is the fungal QQ study carried out with to success the energy saving through fungal-to-bacterial QQ and researchers could decrease the rate of TMP rise-up even for lower aeration intensities [126]. After some results showed that the QQ bacteria located at the periphery of a bead can degrade signal molecules more than the QQ bacteria located inside of the bead have come to light, it was needed to create new immobilization media designs. In 2016, another QQ study with QQ-hollow cylinder was also presented to the readers and this newly developed immobilization medium could increase the surface area and eliminate 
the disadvantage of hollow fibers used as an immobilization medium [129]. QQ-hollow cylinder presented higher QQ activity than did the QQ beads. Furthermore, the shape of the QQ-hollow cylinder provided more physical contact between media and biofilm and this led to a higher efficiency of physical washing. The final step for the immobilization medium design and development is small QQ-sheets that showed 2.5-fold higher biological QQ activity when compared to the QQ activity of QQ beads [129]. Besides, immobilization of QQ enzymes on the membrane surface has been a hot issue and stability problems for enzyme immobilization for QQ applications have started to be recently solved [130]. All the existing QQ media have their own advantages and disadvantages and offer some elements of superiority to others. In this regard, the development of QQ MBR studies is expected to enhance continuously together with innovative $Q Q$ media and new $Q Q$ microorganisms.

Lastly, it is necessary to check the QQ effect on the system performance of MBR and energy and cost saving of QQ applications in MBRs. QQ MBR studies to date showed that there is no negative effect on the system performance of MBR while EPS secretion is inhibited without affecting the bacterial growth and treatment level. Effluent quality was checked by looking to the chemical oxygen demand (COD) and total nitrogen (TN) in various studies and no significant difference in effluent quality between conventional (control) and QQ MBRs [19, 23, 55, 102, 112, 123]. Besides, biofouling in an MBR process is directly associated with energy consumption via TMP increase. When TMP increases to obtain a stable permeate volume during the process, it results in more physical and chemical membrane cleaning, a higher aeration rate and higher suction pump rates. In the study carried out by Jahangir et al. indicated that the application of QQ-vessel in an MBR could decrease the aeration intensity for membrane aeration (the reduction of the aeration rate by $0.5-1.0 \mathrm{~L} / \mathrm{min}$ ) that can be pointed out as one of the main contributors of total energy consumption during an MBR operation [121]. In addition, the reduction in the energy need for the membrane aeration and permeate suction pumps were determined and evaluated by Köse-Mutlu et al. for the use of QQ beads, QQ vessels and RMCF and it was mentioned that these QQ applications resulted in important savings in operating costs and the most feasible one was found as RMCF especially for long-term operations [123]. These are the most powerful arguments of the QQ MBR technology.

\section{Chanllenges in Quorum Quenching}

Although QS inhibition is a promising mechanism to prevent microbial communication, it is better for researchers to be aware of the challenges of QQ. Firstly, there is a variation in the number of LuxI and LuxR homologs between different strains of the same species that were determined for several bacteria. Burkholderia mallei, Burkholderia pseudomallei, and Rhizobium etli, in which the number of LuxR homolog ranges from two to nine, can be given as examples for these species [131]. This situation can result in a challenge for the design of receptor-binding antagonists. Moreover, some of the LuxR homologs are orphans. The existence of these orphans comes up with some questions regarding the possible roles of these orphan LuxR homologs [132]. In addition to these, there is a possibility of the development of a resistance against the QS inhibition. Compensatory mutation leads to the re-organization of social independence with the playing a role as a QS-proficient (a cooperator) instead of QS-deficient (a cheater). It was mentioned in the literature that this mutation is a possible mechanism of bacteria to overcome the QS inhibition [133, 134]. One of the explanations for this situation is the binding of a signaling molecule to another QS regulator [135]. A study showed that the mutation in Qrr sRNA resulted to the failure of Qrr/hapR binding, where hapR is the gene encoding LuxR homolog in $V$. cholera and prevents different genes activities; however, a mutant possessing only one of these four Qrr sRNAs can activate the QS-related activities [136]. This results in a challenge for receptor-binding antagonists to play against the QS system of $V$. cholera. Four strategies to reduce the risk of QQ resistance development that were mentioned in the literature can be listed as follows [137-139]: the use of QQ enzymes that target a broad range of AHLs like lactonase and acylase, the use of different QQ compounds against bacteria, the combination of the QQ approach with other treatments like antibiotics, to create a synergistic effect, and finally targeting the virulence factors.

Another challenge has been the correct detection of QS. As mentioned in this review, there are a few basic biochemistry experiments that can be used by the researchers who aim to have information about the QS molecules. When the first QS signal was discovered in the early 90s, the mass spectrophotometry could not measure up and researchers tended to use and develop some traditional methods based on the light. The challenge is that AHL reporter systems are tended to false positives when used to detect QS inhibitors [140, 141]. It can be basically said that an inhibitor may be interacting with the reporter gene instead of the QS gene. If the researchers analyze a sample, they should take care to confirm that the found molecules are really involved in QS.

\section{Conclusions}

MBR, which are involved in water recovery and reuse, are currently plagued by a range of biofouling problems. One of the most common causes of biofouling is the development of a thickened biofilm layer that results from bacterial adhesion. For this reason, the studies described in this literature review have attempted to develop detailed insights into the QS system and to apply the QQ system as a means of preventing biofouling in MBRs. The results of these studies indicate that extra energy consumption caused by the biofouling problem can be significantly reduced.

If bio-product and biocompatible materials are described as two important elements, while bio-products can involve bacteria and enzymes, the biocompatible material can refer to the immobilization media. For an effective QQ-MBR operation, bio-product and biocompatible material are of equal importance. When the future of this study subject is considered, two essential windows can be opened: 1) there can be the need for new bacteria species and new enzymes originated from these bacteria species or other creatures, and 2) there can be a new open multi-disciplinary research area on biocompatible innovative materials used in immobilization media. 


\section{Acknowledgments}

This work was financially supported by the TUBITAK (the Scientific and Technological Research Council of Turkey), and KORANET (the Korean Scientific Cooperation Network with the European Research Area) under project no 112M739. Tülay Ergön-Can thanks to TUBITAK 2218-National Postdoctoral Research Fellowship Program for financial support.

\section{References}

1. Von Grebmer K, Ringler C, Rosegrant MW, Olofinbiyi T, Wiesmann D, Thompson J. Global hunger index: The challenge of hunger: Ensuring sustainable food security under land, water, and energy stresses. Intl. Food Policy Res. Inst. 2012.

2. Lee S, Park SK, Kwon H, et al. Crossing the border between laboratory and field: Bacterial quorum quenching for anti-biofouling strategy in an MBR. Environ. Sci. Technol. 2016;50: 1788-1795.

3. Meng F, Chae SR, Drew A, Kraume M, Shin HS, Yang F. Recent advances in membrane bioreactors (MBRs): Membrane fouling and membrane material. Water Res. 2009;43:489-1512.

4. Judd S. A review of fouling of membrane bioreactors in sewage treatment. Water Sci. Technol. 2004;492:229-235.

5. Noble J. GE ZeeWeed MBR technology for pharmaceutical wastewater treatment. Membr. Technol. 2006;2006:7-9.

6. Chen W, Liu J. The possibility and applicability of coagulation-MBR hybrid system in reclamation of dairy wastewater. Desalination 2012;285:226-231.

7. Ortiz M, Raluy RG, Serra L, Uche J. Life cycle assessment of water treatment technologies: Wastewater and water-reuse in a small town. Desalination 2007;204:121-131.

8. Pandey A, Singh RK. Industrial waste water treatment by membrane bioreactor system. Elixir Chem. Eng. 2014;70:23772-23777.

9. BCC Research. Global market for membrane bioreactors worth $\$ 488$ million by 2013. International report. Massachusetts, USA; 2008.

10. Grand view research. Membrane bioreactor (MBR) market analysis by product (hollow fiber, flat sheet, multi-tubular), by configuration (submerged, side stream), by application, and segment forecasts, 2018-2025. International report. California, USA; 2017.

11. Drews A. Membrane fouling in membrane bioreactorsCharacterisation, contradictions, cause and cures. J. Membr. Sci. 2010;363:1-28.

12. Bouayed N, Dietrich N, Lafforgue C, Lee CH, Guigui C. Process-oriented review of bacterial quorum quenching for membrane biofouling mitigation in membrane bioreactors (MBRs). Membranes 2016;6:52.

13. Lade H, Paul D, Kweon JH. N-Acyl homoserine lactone-mediated quorum sensing with special reference to use of quorum quenching bacteria in membrane biofouling control. BioMed Res. Int. 2014;2014:162584.

14. Lim AL, Bai R. Membrane fouling and cleaning in microfiltration of activated sludge wastewater. J. Membr. Sci. 2003;216:279-290.
15. Van den Broeck R, Krzeminski P, Van Dierdonck J, et al. Activated sludge characteristics affecting sludge filterability in municipal and industrial MBRs: Unraveling correlations using multi-component regression analysis. J. Membr. Sci.378: 330-338.

16. Adav SS, Lee DJ. Extraction of extracellular polymeric substances from aerobic granule with compact interior structure. J. Hazard. Mater. 2008;154:1120-1126.

17. Tansel B, Sager J, Garland J, Xu S, Levine L, Bisbee P. Deposition of extracellular polymeric substances (EPS) and microtopographical changes on membrane surfaces during intermittent filtration conditions. J. Membr. Sci. 2006;285:225-231.

18. Laspidou CS, Rittmann BE. A unified theory for extracellular polymeric substances soluble microbial products and active and inert biomass. Water Res. 2002;36:2711-2720.

19. Jiang W, Xia S, Liang J, Zhang Z, Hermanowicz SW. Effect of quorum quenching on the reactor performance biofouling and biomass characteristics in membrane bioreactors. Water Res. 2013;47:187-196.

20. Ham SY, Kim HS, Cha E, Park JH, Park HD. Mitigation of membrane biofouling by a quorum quenching bacterium for membrane bioreactors. Biores. Technol. 2018;258:220-226.

21. Greenberg EP. Quorum Sensing in Gram-Negative Bacteria. ASM News 1997;63:371-377.

22. Greenberg EP. Bacterial communication and group behavior. J. Clin. Invest. 2003;112:1288-1290.

23. Kim AL, Park SY, Lee CH, Lee CH, Lee JK. Quorum quenching bacteria isolated from the sludge of a wastewater treatment plant and their application for controlling biofilm formation. J. Microbiol. Biotechnol. 2014;24:1574-1582.

24. Parsek MR, Greenberg EP. Sociomicrobiology: The connections between quorum sensing and biofilms. Trends Microbiol. 2005;13:27-33.

25. Whitehead NA, Barnard AM, Slater H, Simpson NJ, Salmond GP. Quorum sensing in Gram-negative bacteria. FEMS Microbiol. Rev. 2001;25:365-404.

26. Ng WL, Bassler BL. Bacterial quorum-sensing network architectures. Annu. Rev. Genet. 2009;43:197-222.

27. Chen X, Schauder S, Potier N, et al. Structural identification of a bacterial quorum-sensing signal containing boron. Nature 2002;415:545-549.

28. Federle MJ, Bassler L. Interspecies communication in bacteria. J. Clin. Invest. 2003;112:1291-1299.

29. Xavier KB, Bassler BL. Regulation of uptake and processing of the quorum-sensing autoinducer AI-2 in Escherichia coli. J. Bacteriol. 2005;187:238-248.

30. Dobretsov S, Teplitski M, Paul V. Mini-review: Quorum sensing in the marine environment and its relationship to biofouling. Biofouling 2009;25:413-427.

31. Nealson KH, Platt T, Hastings JW. Cellular control of the synthesis and activity of the bacterial luminescent system. J. Bacteriol. 1970;104:313-322.

32. Eberhard A, Burlingame AL, Eberhard C, Kenyon GL, Nealson $\mathrm{KH}$, Oppenheimer NJ. Structural identification of autoinducer of Photobacterium fischeri luciferase. Biochemistry. 1981;20: 2444-2449.

33. Pearson JP, Gray KM, Passador L, et al. Structure of the auto- 
inducer required for expression of Pseudomonas aeruginosa virulence genes. Proc. Natl. Acad. Sci. USA 1994;91:197-201.

34. Cha C, Gao P, Chen YC, Shaw PD, Farrand SK. Production of acyl-homoserine lactone quorum-sensing signals by gram-negative plant-associated bacteria. Mol. Plant Microb. Interact. 1998;11:1119-1129.

35. Fuqua C, Parsek MR, Greenberg EP. Regulation of gene expression by cell-to-cell communication: Acylhomoserine lactone quorum sensing. Annu. Rev. Genet. 2001;35:439-468.

36. Swift S, Lynch MJ, Fish L, et al. Quorum sensing-dependent regulation and blockade of exoprotease production in Aeromonas hydrophila. Infect. Immun. 1999;67:5192-5199.

37. Holden MTG, Chhabra SR, De Nys R, et al. Quorum-sensing cross talk: Isolation and chemical characterization of cyclic dipeptides from Pseudomonas aeruginosa and other Gram-negative bacteria. Mol. Microbiol. 1999;33:1254-1266.

38. Lyon GJ, Mayville P, Muir TW, Novick RP. Rational design of a global inhibitor of the virulence response in Staphylococcus aureus based in part on localization of the site of inhibition to the receptor-histidine kinase. AgrC. Proc. Natl. Acad. Sci. USA. 2000;97:13330-13335.

39. Miller MB, Bassler BL. Quorum sensing in bacteria. Annu. Rev. Microbiol. 2001;55:165-199.

40. Chen X, Schauder S, Potier N, et al. Structural identification of a bacterial quorum sensing signal containing boron. Nature 2002;415:545-549.

41. Miller ST, Xavier KB, Campagna SR, et al. Salmonella typhimurium recognizes a chemically distinct form of the bacterial quorum-sensing signal AI-2. Mol. Cell. 2004;15:677-687.

42. Defoirdt T, Boon N, Bossier P, Verstraete W. Disruption of bacterial quorum sensing: An unexplored strategy to fight infections in aquaculture. Aquaculture 2004;240:69-88.

43. Zhang LH, Dong YH. Quorum sensing and signal interference: Diverse implications. Mol. Microbiol. 2004;53:1563-1571.

44. Chong TM, Koh CL, Sam CK, Choo YM, Yin WF, Chan KG. Characterization of quorum sensing and quorum quenching soil bacteria isolated from Malaysian tropical montane forest. Sensors 2012;12:4846-4859.

45. Lau YY, Sulaiman J, Chen JW, Yin WF, Chan GK. Quorum sensing activity of Enterobacter asburiae isolated from lettuce leaves. Sensors 2013;13:14189-14199.

46. Tan WS, Yunos NYM, Tan PW, et al. Freshwater-borne bacteria isolated from a malaysian rainforest waterfall exhibiting quorum sensing properties. Sensors 2014;14:10527-10537.

47. Zan J, Liu Y, Fuqua C, Hill RT. Acyl-homoserine lactone quorum sensing in the Roseobacter clade. Int. J. Mol. Sci. 2014;15: 654-669.

48. Sandle T. Bacterial adhesion: An introduction. J. Valid. Technol. 2013;19:1-10.

49. Lade H, Paul D, Kweon JH. Isolation and molecular characterization of biofouling bacteria and profiling of quorum sensing signal molecules from membrane bioreactor activated sludge. Int. J. Mol. Sci. 2014;152:2255-2273.

50. Madigan MT, Martinko JM, Stahl DA, Clark DP. Brock biology of microorganisms. 13th ed. USA: Benjamin Cummings Publishers; 2010. p.14-15

51. Yeon KM, Cheong WS, Oh HS, et al. Quorum sensing: A new biofouling control paradigm in a membrane bioreactor for advanced wastewater treatment. Environ. Sci. Technol. 2009;432: 380-385.

52. Fuqua C, Winans SC. Conserved cis-acting promoter elements are required for density-dependent transcription of Agrobacterium tumefaciens conjugal transfer genes. J. Bacteriol. 1996;178: 435-440.

53. Kawaguchi T, Chen YP, Norman RS, Decho AW. Rapid screening of quorum-sensing signal N-Acyl homoserine lactones by an in vitro cell-free assay. Appl. Environ. Microbiol. 2008;74: 3667-3671.

54. Hannah R, Stroke I, Betz N. Beta-Glo® Assay System: A luminescent $\beta$-galactosidase assay for multiple cell types and media. Cell Note. 2003;6:16-18.

55. Oh HS, Kim SR, Cheong WS, Lee CH, Lee JK. Biofouling inhibition in MBR by Rhodococcus sp. $\mathrm{BH}_{4}$ isolated from real MBR plant. Appl. Microbiol. Biotechnol. 2013;9723:10223-10231.

56. Zhu J, Chai Y, Zhong Z, Li S, Winans SC. Agrobacterium bioassay strain for ultrasensitive detection of N-acylhomoserine lactone-type quorum-sensing molecules: detection of autoinducers in Mesorhizobium huakuii. Appl. Environ. Microbiol. 2003;69:6949-6953.

57. Steindler L, Venturi V. Detection of quorum-sensing N-acyl homoserine lactone signal molecules by bacterial biosensors. FEMS Microbiol. Lett. 2006;26:1-9.

58. Rajamani S, Sayre R. Biosensors for the detection and quantification of AI-2 class quorum-sensing compounds. In: Quorum Sensing. New York: Humana Press; 2018. p. 73-88.

59. Culhane K, Jiang K, Neumann A, Pinchuk AO. Laser-fabricated plasmonic nanostructures for surface-enhanced Raman spectroscopy of bacteria quorum sensing molecules. MRS Adv. 2017;2:2287-2294.

60. Wopperer J, Cardona ST, Huber B, Jacobi CA, Valvano MA, Eberl L. A quorum-quenching approach to investigate the conservation of quorum-sensing-regulated functions within the Burkholderia cepacia complex. Appl. Environ. Microbiol. 2006;72:1579-1587.

61. García-Aljaro C, Eberl L, Riedel K, Blanch AR. Detection of quorum-sensing-related molecules in Vibrio scophthalmi. BMC Microbiol. 2008;8:138.

62. Uroz S, Dessaux Y, Oger P. Quorum sensing and quorum quenching: The yin and yang of bacterial communication. ChemBioChem 2009;10:205-216.

63. Whiteley M, Diggle SP, Greenberg EP. Progress in and promise of bacterial quorum sensing research. Nature 2017;551:31-320.

64. Geske GD, O'Neill JC, Blackwell HE. Expanding dialogues: From natural autoinducers to non-natural analogues that modulate quorum sensing in Gram-negative bacteria. Chem. Soc. Rev. 2008;37:1432-1447.

65. Parveen N, Cornell KA. Methylthioadenosine/S-adenosylhomocysteine nucleosidase a critical enzyme for bacterial metabolism. Mol. Microbiol. 2011;79:7-20.

66. Rasmussen TB, Givskov M. Quorum-sensing inhibitors as antipathogenic drugs. Int. J. Med. Microbiol. 2006;152:149-161.

67. Dong YH, Xu JL, Li XZ, Zhang LH. AiiA, an enzyme that inactivates the acylhomoserine lactone quorum sensing signal and attenuates the virulence of Erwinia carotovora. Proc. Natl. 
Acad. Sci. USA 2000;97:3526-3531.

68. Dong YH, Wang LH, Xu JL, Zhang HB, Zhang XF, Zhang LH. Quenching quorum-sensing-dependent bacterial infection by an N-acyl homoserine lactonase. Nature 2001;411:813-817.

69. Leadbetter JR, Greenberg EP. Metabolism of acyl-homoserine lactone quorum-sensing signals by Variovorax paradoxus. J. Bacteriol. 2000;182:6921-6926.

70. Zhang HB, Wang LH, Zhang LH. Genetic control of quorum-sensing signal turnover in Agrobacterium tumefaciens. Proc. Natl. Acad. Sci. 2002;99:4638-4643.

71. Fetzner S. Quorum quenching enzymes. J. Biotechnol. 2015;201: 2-14.

72. Kiran GS, Hassan S, Sajayan A, Selvin J. Quorum quenching compounds from natural sources. Bioresour. Bioproc. Biotechnol. 2017;351-364.

73. Draganov DI, Stetson PL, Watson CE, Billecke SS, La Du BN. Rabbit serum paraoxonase 3 (PON3); is a high density lipoprotein-associated lactonase and protects low density lipoprotein against oxidation. J. Biol. Chem. 2000;275:33435-33442.

74. Teiber JF, Draganov DI, La Du BN. Lactonase and lactonizing activities of human serum paraoxonase (PON1) and rabbit serum PON3. Biol. Chem. Pharmacol. 2003;66:887-896.

75. Chun CK, Ozer EA, Welsh MJ, Zabner J, Greenberg EP. Inactivation of pseudomonas aeruginosa quorum sensing signal by human airway epithelia. Proc. Natl. Acad. Sci. USA 2004;101:3587-3590.

76. Chowdhary PK, Keshavan N, Nguyen HQ, Peterson JA, Gonzales JE, Haines DC. Bacillus megaterium CYP102A1 oxidation of acyl homoserine lactones and acyl homoserines. Biol. Chem. 2007;46:14429-14437.

77. Uroz S, Chabra SR, Cámara M, Williams P, Oger P, Dessaux Y. N-acylhomoserine lactone quorum-sensing molecules are modified and degraded by Rhodococcus erythropolis W2 by both amidolytic and novel oxidoreductase activities. Microbiology 2005;151:3313-3322.

78. Yang F, Wang LH, Wang J, Dong YH, Hu JY, Zhang LH. Quorum quenching enzyme activity is widely conserved in the sera of mammalian species. FEBS Lett. 2005;579:3713-3717.

79. Götz C, Fakete A, Gebefuegi I, et al. Uptake, degradation and chiral discrimination of N-acyl-D/L-homoserine lactones by barley (Hordeum vulgare) and yam bean (Pachyrhizus erosus) plants. Anal. Bioanal. Chem. 2007;389:1447-1457.

80. Ogawa K, Nakajima-Kambe T, Nakahara T, Kokufuta E. Coimmobilization of gluconolactonase with glucose oxidase for improvement in kinetic property of enzymatically induced volume collapse in ionic gels. Biomacromolecules 2002;3: 625-631.

81. Ulrich RL. Quorum quenching: Enzymatic disruption of N-acylhomoserine lactone-mediated bacterial communication in Burkholderia thailandensis. Appl. Environ. Microbiol. 2004;70: 6173-6180.

82. Dong YH, Gusti AR, Zhang Q, Xu JL, Zhang LH. Identification of quorum-quenching $\mathrm{N}$-acyl homoserine lactonases from Bacillus species. Appl. Environ. Microbiol. 2002;68:1754-1759.

83. Carlier A, Uroz S, Smadja B, et al. The Ti plasmid of Agrobacterium tumefaciens harbors an attM-Paralogous gene, aiiB, also encoding $\mathrm{N}$-acyl homoserine lactonase activity. Appl.
Environ. Microbiol. 2003;69:4989-4993.

84. Liu D, Thomas PW, Momb J, et al. Structure and specificity of a quorum-quenching lactonase (AiiB) from Agrobacterium tumefaciens. Biochemistry 2007;46:11789-11799.

85. Chow JY, Xue B, Lee KH, et al. Directed evolution of a thermostable quorum-quenching lactonase from the amidohydrolase superfamily. J. Biol. Chem. 2010;285:40911-40920.

86. Wang WZ, Morohoshi T, Ikenoya M, Someya N, Ikeda T. AiiM, a novel class of $\mathrm{N}$-acylhomoserine lactonase from the leaf-associated bacterium microbacterium testaceum. Appl. Environ. Microbiol. 2010;76:2524-2530.

87. Chow JY, Wu L, Yew WS. Directed evolution of a quorum-quenching lactonase from Mycobacterium avium sub sp. paratuberculosis $\mathrm{K}-10$ in the amidohydrolase superfamily. Biochemistry 2009;48:4344-4353.

88. Afriat L, Roodveldt C, Manco G, Tawfik DS. The latent promiscuity of newly identified microbial lactonases is linked to a recently diverged phosphotriesterase. Biochemistry 2006;45:13677-13686.

89. Mei GY, Yan XX, Turak A, Luo ZQ, Zhang LQ. AidH, an alpha/beta-hydrolase fold family member from an Ochrobactrum sp. strain is a novel N-acylhomoserine lactonase. Appl. Environ. Microbiol. 2010;76:4933-4942.

90. Morohoshi T, Tominaga Y, Someya N, Ikeda T. Complete genome sequence and characterization of the $\mathrm{N}$-acylhomoserine lactone-degrading gene of the potato leaf-associated solibacillus silvestris. J. Biosci. Bioeng. 2012;113:20-25.

91. Merone L, Mandrich L, Rossi M, Manco G. A thermostable phosphotriesterase from the archaeon sulfolobus solfataricus: Cloning overexpression and properties. Extremophiles 2005;9: 297-305.

92. Elias M, Dupuy J, Merone L, et al. Structural basis for natural lactonase and promiscuous phosphotriesterase activities. J. Mol. Biol. 2008;379:1017-1028.

93. Uroz S, Oger PM, Chapelle E, Adeline MT, Faure D, Dessaux Y. A Rhodococcus qsdA-encoded enzyme defines a novel class of large-spectrum quorum-quenching lactonases. Appl. Environ. Microbiol. 2008;74:1357-1366.

94. Riaz K, Elmerich C, Moreira D, Raffoux A, Dessaux Y, Faure D. A metagenomic analysis of soil bacteria extends the diversity of quorum-quenching lactonases. Environ. Microbiol. 2008;10: 560-570.

95. Park SY, Lee SJ, Oh TK, et al. AhlD, an $N$-acylhomoserine lactonase in Arthrobacter sp., and predicted homologues in other bacteria. Microbiology 2003;149:1541-1550.

96. Park SY, Hwang BJ, Shin MH, Kim JA, Kim HK, Lee JK. N-acylhomoserine lactonase-producing Rhodococcus spp. with different AHL-degrading activities. FEMS Microbiol. Lett. 2006;261: 102-108.

97. Lynch MJ, Swift S, Kirke DF, Keevil CW, Dodd CE, Williams P. The regulation of biofilm development by quorum sensing in Aeromonas hydrophila. Environ. Microbiol. 2002;4:18-28.

98. Paul D, Kim YS, Ponnusamy K, Kwon JH. Application of quorum quenching to inhibit biofilm formation. Environ. Eng. Sci. 2009;26:1319-1324.

99. Sauer K, Camper AK. Characterization of phenotypic changes in Pseudomonas putida in response to surface associated 
growth. J. Bacteriol. 2001;183:6579-6589.

100. Xu F, Byun T, Deussen HJ, Duke KR. Degradation of $N$-acylhomoserine lactones the bacterial quorum sensing molecules by acylase. J. Biotechnol. 2003;101:89-96.

101. Kim SR, Oh HS, Jo SJ, et al. Biofouling control with bead-entrapped quorum quenching bacteria in membrane bioreactors: Physical and biological effects. Environ. Sci. Technol. 2013;472:836-842.

102. Yeon KM, Lee CH, Kim J. Magnetic enzyme carrier for effective biofouling control in the membrane bioreactor based on enzymatic quorum quenching. Environ. Sci. Technol. 2009;43: 7403-7409.

103. Lin $\mathrm{YH}, \mathrm{Xu} \mathrm{JL}, \mathrm{Hu}$ J, et al. Acyl-homoserine lactone acylase from Ralstonia strain XJ12B represents a novel and potent class of quorum-quenching enzymes. Mol. Microbiol. 2003;47:849-860.

104. Romero M, Diggle SP, Heeb S, Camara M, Otero A. Quorum quenching activity in Anabaena sp. PCC 7120: Identification of AiiC a novel AHL-acylase. FEMS Microbiol. Lett. 2008;280:73-80.

105. Huang JJ, Han JI, Zhang LH, Leadbetter JR. Utilization of acyl-homoserine lactone quorum signals for growth by a soil pseudomonad and Pseudomonas aeruginosa PAO1. Appl. Environ. Microbiol. 2003;69:5941-5949.

106. Sio CF, Otten LG, Cool RH, et al. Quorum quenching by an N-acyl-homoserine lactone acylase from Pseudomonas aeruginosa PAO1. Infect. Immun. 2006;74:1673-1682.

107. Shepherd RW, Lindow SE. Two dissimilar N-acyl-homoserine lactone acylases of Pseudomonas syringae influence colony and biofilm morphology. Appl. Environ. Microbiol. 2009;75: 45-53.

108. Chen CN, Chen CJ, Liao CT, Lee CY. A probable aculeacin A acylase from the ralstonia solanacearum GMI1000 is $\mathrm{N}$-acyl-homoserine lactone acylase with quorum quenching activity. BMC Microbiol. 2009;9:89.

109. Morohoshi $\mathrm{T}$, Nakazawa S, Ebata A, Kato N, Ikeda $\mathrm{T}$. Identification and characterization of $\mathrm{N}$-acylhomoserine lactone-acylase from the fish intestinal Shewanella sp. strain MIB015. Biosci. Biotechnol. Biochem. 2008;72:1887-1893.

110. Park SY, Kang HO, Jang HS, Lee JK, Koo BT, Yum DY. Identification of extracellular $N$-acylhomoserine lactone acylase from a Streptomyces sp. and its application to quorum quenching. Appl. Environ. Microbiol. 2005;71:2632-2641.

111. Chan KG, Atkinson S, Mathee K, et al. Characterization of $\mathrm{N}$-acylhomoserine lactone-degrading bacteria associated with the zingiber officinale ginger; rhizosphere: Co-existence of quorum quenching and quorum sensing in Acinetobacter and Burkholderia. BMC Microbiol. 2011;11:51.

112. Cheong WS, Lee $\mathrm{CH}$, Moon $\mathrm{YH}$, et al. Isolation and identification of indigenous quorum quenching bacteria pseudomonas sp. 1A1 for biofouling control in MBR. Ind. Eng. Chem. Res. 2013;52:10554-10560.

113. Uroz S, Oger P, Chhabra SR, Camara M, Williams P, Dessaux Y. N-acyl homoserine lactones are degraded via an amidolytic activity in Comamonas sp. strain D1. Arch. Microbiol. 2006;187:249-256.

114. Lithgow JK, Wilkinson A, Hardman A, et al. The regulatory locus cinRI in Rhizobium leguminosarum controls a network of quorum-sensing loci. Mol. Microbiol. 2000;37:81-97.

115. Bassler BL, Losick R. Bacterially speaking. Cell 2006;125: 237-246.

116. Koch B, Liljefors T, Persson T, Nielsen J, Kjelleberg S, Givskov M. The LuxR Receptor: The sites of interaction with quorum-sensing signals and inhibitors. Microbiology 2005;151: 3589-3602.

117. Chen G, Swern LR, Swern DL, et al. A strategy for antagonizing quorum sensing. Mol. Cell 2011;42:199-209.

118. Jimenez PN, Koch G, Thompson JA, Xavier KB, Cool RH, Quax WJ. The multiple signaling systems regulating virulence in pseudomonas aeruginosa. Microbiol. Molecul. Bio. Rev. 2012;76:46-65.

119. Kim JH, Choi DC, Yeon KM, Kim SR, Lee CH. Enzyme-immobilized nanofiltration membrane to mitigate biofouling based on quorum quenching. Environ. Sci. Technol. 2011;45:1601-1607.

120. Oh HS, Yeon KM, Yang CS, et al. Control of membrane biofouling in MBR for wastewater treatment by quorum quenching bacteria encapsulated in microporous membrane. Environ. Sci. Technol. 2012;46:4877-4884.

121. Jahangir D, Oh HS, Kim SR, Park PK, Lee CH, Lee JK. Specific location of encapsulated quorum quenching bacteria for biofouling control in an external submerged membrane bioreactor. J. Membr. Sci. 2012;411-412,130-136.

122. Cheong WS, Kim SR, Oh HS, et al. Design of quorum quenching microbial vessel to enhance cell viability for biofouling control in membrane bioreactor. J. Microbiol. Biotechnol. 2014;24:97-105.

123. Köse-Mutlu B, Ergön-Can T, Koyuncu İ, Lee CH. Quorum quenching MBR operations for biofouling control under different operation conditions and using different immobilization media. Desalin. Water Treat. 2015;17696-17706.

124. Lee B, Yeon KM, Shim J, et al. Effective antifouling using quorum-quenching acylase stabilized in magnetically- separable mesoporous silica. Biomacromolecules 2014;15:1153-1159.

125. Kim SR, Lee KB, Kim JE, et al. Macroencapsulation of quorum quenching bacteria by polymeric membrane layer and its application to MBR for biofouling control. J. Membr. Sci. 2015;437:109-117.

126. Lee KB, Lee SK, Lee SH, et al. Fungal quorum quenching: A paradigm shift for energy savings in membrane bioreactor (MBR) for wastewater treatment. Environ. Sci. Technol. 2016;50:10914-10922.

127. Lee SK, Lee SH, Lee KB, et al. Effect of shape and size of quorum quenching medium on biofouling control in membrane bioreactors for wastewater treatment. J. Microbiol. Biotechnol. 2016;26:1746-1754.

128. Lee SH, Lee S, Lee K, et al. More efficient media design for enhanced biofouling control in a membrane bioreactor: quorum quenching bacteria entrapping hollow cylinder. Environ. Sci. Technol. 2016;50:8596-8604.

129. Nahm CH, Choi DC, Kwon H, et al. Application of quorum quenching bacteria entrapping sheets to enhance biofouling control in a membrane bioreactor with a hollow fiber module. J. Membr. Sci. 2017;526:264-271.

130. Lee J, Lee I, Nam J, Hwang DS, Yeon KM, Kim J. Immobilization 
and stabilization of acylase on carboxylated polyaniline nanofibers for highly effective antifouling application via quorum quenching. ACS Appl. Mater. Interf. 2017;9:15424-15432.

131. Hong KW, Koh CL, Sam CK, Yin WF, Chan KG. Quorum quenching revisited-from signal decays to signalling confusion. Sensors. 2012;12:4661-4696.

132. Patankar AV, González JE. Orphan LuxR regulators of quorum sensing. FEMS Microbiol. Rev. 2009;33:739-756.

133. Sandoz KM, Mitzimberg SM, Schuster M. Social cheating in Pseudomonas aeruginosa quorum sensing. Proceed. Nat. Acad. Sci. 2007;104:15876-15881.

134. Beatson SA, Whitchurch CB, Semmler AB, Mattick JS. Quorum sensing is not required for twitching motility in Pseudomonas aeruginosa. J. Bacteriol. 2002;184:3598-3604.

135. Choi Y, Park HY, Park SJ, et al. Growth phase-differential quorum sensing regulation of anthranilate metabolism in pseudomonas aeruginosa. Mol. Cell. 2011;32:57-65.
136. Bardill JP, Zhao X, Hammer BK. The Vibrio cholerae quorum sensing response is mediated by Hfq-dependent sRNA/mRNA base pairing interactions. Mol. Microbiol. 2011;80:1381-1394.

137. Defoirdt T, Boon N, Bossier P. Can bacteria evolve resistance to quorum sensing disruption? PLOS Pathogens. 2010;6, e1000989.

138. Estrela $\mathrm{AB}$, Abraham WR. Combining biofilm-controlling compounds and antibiotics as a promising new way to control biofilm infections. Pharmaceuticals 2010;3:1374-1393.

139. Clatworthy AE, Pierson E, Hung DT. Targeting virulence: A new paradigm for antimicrobial therapy. Nat. Chem. Biol. 2007;3:541-548.

140. Kalia VC. Quorum sensing and its biotechnological applications. Springer Nature; 2018. p. 119-131.

141. Ran T, Zhou CS, Xu LW, et al. Initial detection of the quorum sensing autoinducer activity in the rumen of goats in vivo and in vitro. J. Integ. Agri. 2016;15:2343-2352. 